\title{
Circuit
}

Musiques contemporaines

\section{Entretien avec Charles de Mestral (2008)}

\section{Mario Gauthier}

Volume 23, numéro 1, 2013

URI : https://id.erudit.org/iderudit/1017212ar

DOI : https://doi.org/10.7202/1017212ar

Aller au sommaire du numéro

Éditeur(s)

Les Presses de l’Université de Montréal

ISSN

1183-1693 (imprimé)

1488-9692 (numérique)

Découvrir la revue

Citer cet article

Gauthier, M. (2013). Entretien avec Charles de Mestral (2008). Circuit, 23(1),

67-67. https://doi.org/10.7202/1017212ar

Ce document est protégé par la loi sur le droit d'auteur. L'utilisation des services d'Érudit (y compris la reproduction) est assujettie à sa politique d'utilisation que vous pouvez consulter en ligne.

https://apropos.erudit.org/fr/usagers/politique-dutilisation/
Cet article est diffusé et préservé par Érudit.

Érudit est un consortium interuniversitaire sans but lucratif composé de l'Université de Montréal, l'Université Laval et l'Université du Québec à Montréal. Il a pour mission la promotion et la valorisation de la recherche. https://www.erudit.org/fr/ 
EXCLUSIVITÉ WEB

\section{Entretien avec \\ Charles de Mestral (2008)}

Mario Gauthier

Document audio disponible en ligne sur le site web de Circuit: www.revuecircuit.ca
Sonde est un groupe de compositeurs improvisateurs montréalais composé de Andrew Culver, Keith Daniel, Charles de Mestral, Pierre Dostie, Chris Howard, Robin Minard et Linda Pavelka. Ils ont été actifs de 1975 à 1987. Charles de Mestral, interviewé au printemps 2008, situe quelques enjeux qu'impliquait leur pratique, très avant-gardiste à l'époque, dans laquelle l'ensemble conciliait instruments inventés, appareillage électroacoustique et improvisation méditative.

Nous remercions la Communauté électroacoustique canadienne (CEC), commanditaire initial de cet entretien. Sa version intégrale a été mise en ligne dans le Numéro spécial $10^{e}$ anniversaire: Projet d'archivage Concordia (PAC) / 1oth Anniversary Special Issue: The Concordia Archival Project (CAP) du magazine web eContact! de la CEC (vol. 10, $\mathrm{n}^{\circ} \mathrm{x}$, décembre 2008)1.

Nous remercions également Éric Mattson, grâce à qui la musique de Sonde, inédite ou devenue introuvable, est maintenant disponible en disque compact chez Oral Records. Les musiques utilisées proviennent des disques En ondes (ORAL_CD16) et En concert (ORAL_CD21) ${ }^{2}$.
1. Le numéro est disponible à l'adresse suivante: <http://cec.sonus.ca/ education/archive/10_x/index_fr.html> (consulté le 15 avril 2013).

2. Pour référence complète, on consultera le site d'Oral Records: $<$ www.oral.qc.ca/index2.php> (consulté le 15 avril 2013). 